\title{
The Performance of an Importer in Mediating the Influence of Export Incentives on the Performance of an Exporter
}

Submitted 13/01/21, $1^{\text {st }}$ revision $12 / 02 / 21,2^{\text {nd }}$ revision $28 / 02 / 21$, accepted $27 / 03 / 21$

\author{
Pornlapas Suwannarat ${ }^{1}$
}

Abstract:

Purpose: The purpose of this study is to ascertain the mediation effect of the performance of an importer on the impact of export incentives over the performance of an exporter.

Design/Methodology/Approach: A postal survey of 400 export firms was conducted. Samples were accessed from the official database of the Department of Export Promotion, the Ministry of Commerce, Thailand.

Findings: A full mediation of the role performance of an importer on the impact of export incentives on the performance of an exporter has been found. Also, export incentives in the types of non-monetary incentives of creditable channel policies and monetary incentives as price and financial issues have significantly and positively affected on the role performance of an importer.

Practical Implications: Present and future exporters can benefit from the results of this study by utilizing proper export incentives to motivate importers in promoting and supporting sales of exporters internationally since the role of an importer is so vital for the success of exporters. Firm executives and policy makers also benefit from the findings of the study since an awareness of the determinants of the role performance of an overseas importer, especially the export incentives, could facilitate firms' strategies.

Originality/Value: The study provides the original insights in illustrating the mediation effect of the role performance of an importer on the impact of export incentives in the forms of monetary and price issues and non-monetary issues over the performance of an exporter.

Keywords: Export, export incentives, performance of exporters, role performance of importers, ASEAN.

JEL Code: M16.

Paper Type: Research study.

\footnotetext{
${ }^{1}$ Associate Professor in International Business, Mahasarakham Business School, Mahasarakham University, Maha Sarakham, Thailand E-mail:pornlapas.s@mbs.msu.ac.th
} 


\section{Introduction}

According to Obadia, Bello, and Gilliland (2015), "in the export channel, exporters often intervene in the business activities of their foreign importers by offering extra high margins, special discounts, and other incentives in an attempt to increase the importer's marketing efforts on their behalf". Likewise, Gilliland (2003) also points out that the exporter-initiated incentive programs play a key role in maintaining relationships with independent channel intermediaries. Correspondingly, Obadia and Stottinger (2015) argue that when exporters use foreign independent intermediaries to promote their brands in international markets, by setting appropriate incentives, is vital in the success or failure of export ventures.

To achieve adequate performance in foreign markets, existing research has highlighted a few incentives by exporters to motivate overseas importers to successfully push their products in the international markets (Obadia, Bello, and Gilliland, 2015; Obadia and Stottinger, 2015, Gilliland and Kim, 2014; Gilliland, 2004; 2003). According to Obadia and Vida (2011), exporter's success depends on the willingness of importers to excel in performing both straightforward tasks such as selling to current accounts as well as more difficult, complex tasks such as market development and new product introduction. If the importer is poorly motivated to perform its tasks, not only do an exporter's sales suffer, but its customers may become dissatisfied and the long-term potential of the foreign market can be undermined (Obadia, Bello, and Gilliland, 2015; Prime, Obadia, and Vida, 2009).

Obadia and Stottinger (2015) and Prime, Obadia, and Vida (2009) contend that importers (which may refer as resellers, intermediaries, or distributors) usually carry products from more than one supplier (exporters), giving them the freedom to decide which products to promote actively in the foreign market and which ones not to promote. As such, the importer has alternatives if it is not satisfied with the return of one range of products. This puts the exporter in a situation of internal competition with the importer's other product lines. Hence, to manage the export channel relationship via overseas importers successfully, exporters must overcome this internal competition and motivate the importers to dedicate appropriate efforts to promote their products (Obadia and Stottinger, 2015). Exporters must provide the importers with superior benefits and keep the working network fruitful and progressive (Obadia and Stottinger, 2015; Argouslidis and Indounas, 2010; Banerjee et al., 2012; Cavusgil, 1996; Hallén, Johanson, and Seyed-Mohamed, 1991; Rosenbloom, 1990).

This study additionally contributes to the export literature by grounding on agency theory to explain the export incentives as the exporters employ to overcome internal competition and achieve superior performance. Agency theory has been used to explain the impact of monitoring on export channel relationships (see for example Obadia, Bello, and Gilliland, 2015; Gilliland, 2004; Obadia and Vida, 2011; Aulakh, Kotabe, and Sahay, 1996; Bello and Gilliland, 1997). As well, the mediation role of 
importer role performance mediating between export incentives of exporters and exporter performance have been revealed in this study. The second contribution resides in a study measurement approach of export incentives, which both monetary and non-monetary incentives have been investigated to uncover the effectiveness of them in dealing with internal competition. From a managerial point of view, this study also yields usable recommendations for exporters that employ independent overseas importers since the suggestion of using effective incentives grounding on the results of this study can be made to manage channel relationships and improve export performance.

In addition, several researchers (Suwannarat 2016a; 2017; Indro and Richards, 2007) have pointed out that the economy of the Association of Southeast Asian Nations (ASEAN) has grown considerably in the past three decades, particularly, the ASEAN4 countries of Thailand, Malaysia, the Philippines, and Indonesia. According to Thomsen (1999) cited in Suwannarat (2016b) "the switch to export promotion policies for the ASEAN4 countries began at different times in different countries. Malaysia started to promote exports in as early as the 1970s but just like Thailand, the real export push only began to thrive in the mid-1980s. Following this, Indonesia and the Philippines adopted the export-oriented approach in the late 1990s". On the basis of such evidence, one can expect an increased interest in the exporting trade of the ASEAN4 countries and the middleman role of overseas importers in facilitating and promoting exports.

The paper is organized as follows: in the next section, a review of the pertinent literature with a focus on the relevance of export incentives and agency theory for the research question and developing a series of research hypotheses in parallel have been shown. After outlining the research methodology in detail, the presentation of the study results with a discussion on the research implications of the findings have been made before the outlining has been presented in respect to how exporters may use the findings to manage their relations more successfully to importers through export incentives.

\section{Literature Review}

\subsection{The Export Incentives}

According to Obadia, Bello, and Gilliland (2015), export incentive literature differentiates between high-powered incentives (HPIs), defined as immediate, typically monetary, rewards for accomplishing specific tasks (e.g., bonus payments for exceeding sales quotas), and low-powered incentives (LPIs), defined as motivators, often non-monetary, that do not involve immediate rewards but enable a partner to earn increased rents through continued participation in the relationship (e.g., offering special training, exclusive sales territories, managerial assistance) (Gilliland, 2004; Williamson, 1991). 
Gilliland (2003) defines export incentives as "behaviors or policies described in the supplier's standard operating agreement that are designed to motivate active intermediary support of the supplier's agenda". A key element of any incentive offering is the nature in which it compensates the reseller for its efforts (Chu and Desai, 1995; Zenger and Marshall, 2000). Many incentives compensate the importers directly by providing monetary rewards for the performance of specific tasks (e.g., trade discounts, cash rebates). Other incentives that are not contingent on specific performance (e.g., co-op advertising kits, sales support information) compensate the importers indirectly through eventual sales or margin increases. In short, the export incentives include trade discounts and other means of direct compensation as well as channel incentives (e.g., services performed, information shared, pledge made, and other support tools) (Gilliland, 2003; 2004).

\subsubsection{Credible Channel Policies}

According to Gilliland (2003); Obadia, Bello, and Gilliland (2015), credible channel policies are tangible, supportive operating principles that demonstrate a supplier's desire to sustain its intermediary channel. While channel policies typically specify roles and obligations, particularly unique or attractive policies motivate resellers to support the supplier. Two subcategories emerged; pledges to the channel and conflict resolution strategies. Pledges to the channel are distinct actions taken by the supplier that support its indirect selling model and/or intermediary network. Visible dedication to the channel is important as resellers are threatened by disintermediation due to integrated supply and supplier-direct electronic commerce. Conflict resolution strategies are actions overtly taken to preempt or reduce channel conflict. For instance, one firm compensates their resellers for account development efforts if an eminent sale is stolen by a channel rival.

\subsubsection{Price and Financial Incentives}

According to Obadia, Bello, and Gilliland (2015), "the power of an incentive refers to its immediacy (i.e., the closeness of task performance to its monetary compensation) and to its intensity magnitude (i.e., the size and certainty of the monetary payoff) (Gilliland, 2004; Williamson, 1991)”. Price and Financial incentives are both immediate and intense because they are tangible, recognizable forms of specific monetary compensation paid immediately for achieving a particular task, such as selling a product, meeting a pre-established goal, or financing a deal (Benabou and Tirole, 2003).

These incentives include immediate incentives to see and financial programs. Immediate incentive to sell represent increases in cash-based rewards paid to resellers for performance. These include larger margin discounts, extra cash bonuses, and other methods that increase the magnitude of reward for performing a task. Also included are other earned instrumental rewards such as trips or entertainment. Financial programs are tools that reduce the monetary cost of purchase for the reseller, the end user, or both. These include special financing arrangements, enhanced bid approval processes, and consideration of lower pricing to make 
resellers more competitive (Gilliland, 2003; 2004).

\subsubsection{Market Development Support}

Market development support refers to programs that help resellers perform the various activities that build business in their local territories (Gilliland, 2004). The extent of support is of vital importance to resellers because it influences their ability to profit from the brand. It is important to suppliers because it allows control of the marketing strategy in the reseller's territory (Fites, 1996; Frazier and Lassar, 1996; Frazier, 1999).

Market development support can be in many forms. For instance, sales support information, which includes presale, postsale, applications, technical, and service information, provides intelligence to the reseller, while market development tools are assistance programs and aids for resellers to use to market and sell the supplier's brand (i.e., sales leads, trade show support). Personal assistances occur when the supplier devotes personnel to support the reseller. Assistance may come in the form of field or home office support and may be dedicated to an individual reseller or shared with other resellers. Supplier personnel support technical and selling functions and offer guidance and advice, while ensuring effective representation of the brand. Discretionary funds refer to monetary support that comes with few obligations or directives for use. Discretionary funds are valued by resellers because they are, by definition, compatible with reseller goals (Bergen, Dutta, and Walker, 1992). Last but not least, certification programs make market development resources available to resellers that meet certain requirements (i.e., pass proficiency tests, hold a certain level of inventory, or demonstrate selling success) (Obadia, Bello, and Gilliland, 2015; Gilliland, 2003; 2004).

\subsubsection{Supplemental Contact}

According to Gilliland $(2003$; 2004), supplemental contact refers to programs to exchange information that go above and beyond day-to-day operations and sales support information. Supplemental contact incentives go above and beyond by packaging information to substantively increase the capabilities of resellers and, thus, the quality content inherent in their performance of the channel functions. By improving information content and method of delivery, the reseller is able to communicate, learn, and transact daily business in an enhanced way. Communications programs keep resellers abreast of recent developments through face-to-face meetings, video broadcasts, newsletters, and electronic contact. While programs promote the downstream dissemination of data, some include an opportunity for resellers to provide feedback. Automated information and automated transaction are internet-based enhancements to normal communications and transaction processes. Both provide an easier exchange of formal and informal information that is rich in content (Mohr, 1990). Recent technical developments within the software industry have made the automation of traditional channel tasks more feasible (Mirani, Moore, and Weber, 2001). 
With automated information, the supplier provides intelligence (including regular communications, operational policies, and sales, competitive, service, product, and pricing information) in a format that is substantially more thorough, more accessible, and more customizable than before. The Internet allows resellers to quickly access, browse, and download large amounts of data for reference or training, enhancing productivity (Mirani, Moore, and Weber, 2001). Automated transactions enhance business exchange. Sophisticated electronic commerce tools give resellers the ability to configure, price, and place orders, check order status, make warranty claims, and file reports online (Gilliland, 2003; 2004).

\subsubsection{End-User Encouragements}

End-User Encouragements refer to supplier efforts that, when combined with reseller support, provide unique, value-enhancing solutions (Gilliland, 2003). Importantly, these new solutions offer resellers additional opportunities outside their traditional industry, application, and geographic territory (Anderson and Narus, 1999). Reseller marketing occurs when the supplier actively promotes the reseller and/or its products. Methods include making reseller-developed products available for sale to end-users nationwide, advertising the benefits of resellers to end-users, and referring and linking end-users to resellers. While this seems converse to traditional downstream selling models, savvy suppliers recognize they can capitalize on the unique value added by channel partners. Co-marketing refers to supplier-initiated joint efforts to pursue targeted accounts. While almost all suppliers support reseller marketing activities, here the supplier takes a proactive role in identifying, selecting, and pursuing potential customers with the reseller. Risk reduction programs lower customer switching costs by decreasing their required investment. "These programs, which often allow end-users to 'kick the tires' before purchase, are offered through the reseller and increase its opportunity of closing the sale" (Gilliland, 2003, p. 62).

\subsection{Agency Theory}

According to Peng and York (2001), agency theory is concerned with resolving two problems that can occur in principle-agency relationships. The first is the agency problem that arises when (a) the desires or goals of the principal and agent conflict and (b) it is difficult or expensive for the principal to verify what the agent is actually doing. The problem is that the principal cannot verify that the agent has behaved appropriately. The second is the problem of risk sharing that arises when the principal and agent have different attitudes toward risk. The problem is that the principal and the agent may prefer different actions because of the different risk preferences (Jensen and Meckling, 1976; Lassar and Kerr, 1996).

An agency relationship is prevalent whenever one party, the principal (the exporter) depends on another party, the agent (the importer) to undertake some action on the principal's behalf (Obadia and Stottinger, 2015). To manage the relationship efficiently, agency theory establishes the optimal form of contract (agent compensation) between two parties (Eisenhardt, 1989) that aligns the exporter's and 
the importer's interests. In this context, the importer's risk aversion plays a key role. In agency theory, the agent is defined as being risk averse (in contrast to the principal, who is usually mapped as risk neutral) (Obadia, Bello, and Gilliland, 2015). The importer's risk aversion may result from different reasons. For instance, importer depends on the exporter to supply attractive products at competitive prices (Lassar and Kerr, 1996) or limited flexibility to diversify its engagements after committing to an exporter (Bergen, Dutta, and Walker, 1992). Risk also arises as the importer can only partly influence its economic performance in the market because uncontrollable effects such as competitor actions, governmental policies, or economic conditions similarly affect the business. To mitigate risk, the importer may develop a portfolio of products in the same or different product categories, thus creating a set of potential revenue sources from which it can select the most rewarding (Obadia and Stottinger, 2015; Bergen, Dutta, and Walker, 1992).

For the exporter, this establishes a situation of internal competition (Obadia and Stottinger, 2015). Internal competition does not arise only because of the distributor carrying brands competing for the same market segment. Even brands in different product categories can become competitors when observed through the logic of internal competition. Indeed, internal competition does not depend on the competing nature of the products, it rather refers to the competition between several suppliers for one distributor's efforts. To gain the importer's attention, the exporter needs to provide attractive benefits to the importer (Bergen, Dutta, and Walker 1992). From an agency theory perspective, such incentives are supplemental revenues provided by the principal to the agent.

In a classic principal-agent relationship, the agent works for one principal at a time and therefore must terminate a contract before accepting a new one. In the channel setting, the distributor can take multiple contracts simultaneously. This increases the level of (internal) competition the exporter faces because the importer can have multiple alternative suppliers, and in this situation, the importer does not incur any switching cost for moving from one supplier to the other. Thus, the channel context requires the exporters to provide incentives to their importers (resellers) if they want to secure a proper attention to their products (Obadia, Bello, and Gilliland, 2015; Obadia and Stottinger, 2015).

In the line with Obadia, Bello, and Gilliland (2015), Obadia and Stottinger (2015), Banerjee et al., (2012), Gilliland (2004; 2003), monetary and non-monetary support can be assimilated to the provision of incentives to the importer by the exporter because they allow the exporter to offer supplemental revenues and benefits to the importer. Indeed, by providing incentives, exporters can increase the gains that their distributor achieve with their products to a level that is superior to what the reseller's alternative suppliers can offer. The exporter expects these incentives to motivate the importer to focus on the exporter's offering. By doing so, the importer maximizes its revenue. 
According to previous study of Obadia, Bello, and Gilliland (2015), the results indicate that export incentives positively affected on importer role performance as well as the relationship quality between exporters and importers. Also, Obadia and Stottinger (2015) find from their study that export price manipulation improved importer role performance. Hence, the following hypothesis (H1) has been established:

H1: The export incentives in the forms of price and monetary incentives as well as non-monetary incentives provided by exporter positively influence on the role performance of overseas importer.

According to Obadia and Stottinger (2015), the importer's role performance is one of the key factors attributing to the success of exporters. The role performance has been used mainly in relation to the exporter (Kumar and Bergstrom, 2007; Skarmeas et al., 2008). Frazier (1983) argues that for a fruitful dyadic relationship, role performance needs to work both ways. When two firms engage in a business relationship, each assumes certain tasks and responsibilities and relies on the other party to reciprocate based on the respective channel position (Frazier, 1983). Several researchers (Obadia, Bello, and Gilliland, 2015; Obadia and Stottinger, 2015; Kumar and Bergstrom, 2007) explain that the exporter's incentives motivate the importer to maintain the exchange relationship and fulfill its role accordingly.

Furthermore, Frazier (1983) argues that "when actual exchanges of products, services, and information begin, the role performance of each firm (how well a channel role is actually carried out) will determine, in a large part, the outcomes, both actual and perceived, achieved in the relationship (e.g., sales, profits)." The appropriate agent incentives (provided through the export pricing policy) increase agent effort (the distributor role performance) which in turn increases the principal benefits (the exporter economic performance). Simply put, adequate importer role performance leads to exporter economic performance. In addition, according to their study, Obadia and Stottinger (2015) finds that importer role performance mediates the impact of export price manipulations on export economic performance. Considering these considerations, the second hypothesis (H2) and the third hypothesis (H3) have been made:

H2: The role performance of overseas importer positively influences on the performance of exporter.

H3: The role performance of overseas importer mediates the influence of the export incentives on the performance of exporter.

On this basis, the appropriate conceptual framework of the study is shown in Figure 1. 


\section{Research Methodology}

\subsection{Sample and Data Collection Method}

This study used the official database of export firms [trading firms] provided by the Department of Export Promotion, Ministry of Commerce, Thailand. There was a total of 1,988 firms. An adequate sampling was determined by using the sample size table of Krejcie and Morgan (1970). A simple random sample of 400 export firms were retrieved via a random numbering table that was identified from the population firms. Postal questionnaires using the five Likert- scale point was formulated in Thai and English and then sent to the sample firms. They were addressed to the target respondents, the chief executive officer (CEO), managing director, export manager, marketing manager, and related top managers of the export firms. The response rate was 26.25 percent. To test non-response bias, a comparison was made between early and late respondents, as suggested by Armstrong and Overton (1977). The results show no significant differences between early and late responses.

Figure 1. Conceptual Framework

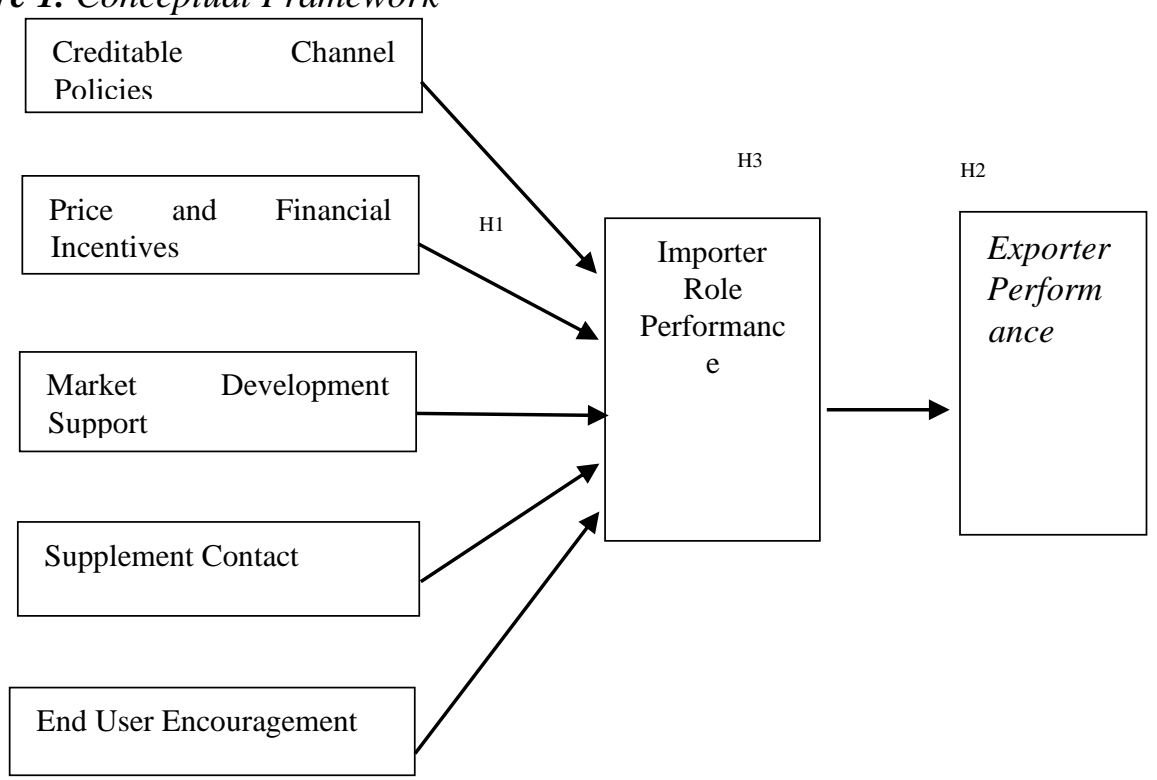

\subsection{Questionnaire Design}

The questionnaire and specific questions were designed to provide answers to the research questions required to fulfil the aim and objectives of this study. They are grounded on the research design and methods of Dillman (2000). A number of questions from previous studies (Suwannarat, 2016, 2017; Obadia, Bello, and Gilliland, 2015; Obadia and Stottinger, 2015) also provided guidance in creating the questionnaire. 


\subsection{The Measurement}

The constructs of independent variables in this research are the export incentives. From previous studies these are price and financial incentives (Obadia and Stottinger, 2015; Gilliland, 2003; 2004; Benabou and Tirole, 2003; Holmstrom and Milgrom, 1994), and non-monetary incentives of creditable channel policies, market development support, supplement contact, end user encouragement (Obadia, Bello, and Gilliland, 2015; Gilliland, 2003; 2004; Mirani, Moore, and Weber, 2001; Fites, 1996; Frazier and Lassar, 1996; Bergen, Dutta, and Walker, 1992).

The Mediating Variable is the importer's role performance which has been developed from previous studies of Obadia and Stottinger (2015), Obadia, Bello, and Gilliland (2015). The dependent variable is the exporter's performance. It is measured by six items dealing with performance of an export firm. These include the acquisition of new clients, the retention of existing clients, goal achievement, market share, income, and export growth, which were developed from the studies of Obadia and Stottinger (2015), Aaby and Slater (1989), Shoham (1998), Zou, Taylor, and Osland (1998).

\subsection{Reliability and Validity}

Reliability of the measurements was computed by Cronbach's Alpha coefficients. In the scale of reliability, the coefficient values in this study are greater than 0.70 ; this can be interpreted as meaning that the scale of all measures is internally consistent (Nunnally and Bernstein, 1994). Factor analysis is employed to test the validity of data in the questionnaire. According to the rule of thumb stated by Nunnally and Bernstein (1994), if all factor loadings are greater than 0.40 cut-offs and are statistically significant, this can be taken as showing the validity of the instruments. All the results of this study comply with this rule. All the results of this study comply with this rule, as can be seen in Table I.

Table 1. Result of Measure Validation

\begin{tabular}{|l|c|c|}
\hline \multicolumn{1}{|c|}{ Variables } & Factor Loadings & Reliability (Alpha) \\
\hline Creditable Channel Policies & $0.655-0.881$ & 0.729 \\
Price and Financial Incentives & $0.668-0.856$ & 0.773 \\
Market Development Support & $0.739-0.914$ & 0.857 \\
Supplemental Contact & $0.545-0.895$ & 0.712 \\
End-User Encouragement & $0.695-0.855$ & 0.797 \\
Importer Role Performance & $0.756-0.911$ & 0.873 \\
Exporter Performance & $0.711-0.957$ & 0.846 \\
\hline
\end{tabular}

\section{Source: Own study.}

Table 2 shows the correlation matrix of the variables. Possible problems relating to multi-collinearity occur when two or more independent variables are linearly related 
very closely. This problem was also monitored. Hair et al. (2006) argue that a correlation with a value above 0.80 should be considered a serious problem. After the simple correlations between independent variables and standard errors of the estimated coefficients had been examined, the data showed that there was no serious multi-collinearity which would distort the efficiency of the estimate. Also, the variance inflation factor (VIF) has been used to check the multi-collinearity problem between the independent variables. The VIF value of this study is below the cut-off value of 10; this indicates that the independent variables do not correlate to any great extent with each other (Neter et al., 1985).

\subsection{Control Variables}

Firm size and firm operational capital are the control variables of the study. Firm size was measured by the number of employees, whereas firm operational capital was established from the value of operational capital. According to the literature (Husted and Allen, 2007; Ciliberti, Pontrandolfo and Scozzi, 2008), larger firms tend to have more resources and to be more active than smaller firms in strategic planning, as well as better utilizing resources to accomplish the firm's goals. Hence, the dummy variables distinguish firms' size and firms' operational capital.

\subsection{Statistical Technique}

Ordinary least square (OLS) regression analysis is adopted to test the hypothesis relationships between the resources, the ability to reduce export-related costs and intermediaries' performance. According to Aulakh et al. (2000), if all dependent, independent and control variables in the research are neither nominal data nor categories data, OLS is the appropriate method for examining the hypotheses' relationships.

Table 2. Correlation Matrix Result of Measure Validation

\begin{tabular}{|c|c|c|c|c|c|c|c|c|}
\hline & Credit & Price & Market & Supp & EndU & OvPer & $\begin{array}{c}\text { Exper } \\
\mathrm{t}\end{array}$ & VIF \\
\hline $\begin{array}{l}\text { Creditable Channel } \\
\text { Policies (Credit) }\end{array}$ & 1 & & & & & & & 1.682 \\
\hline $\begin{array}{l}\text { Price and Financial } \\
\text { Incentive (Price) }\end{array}$ & $\begin{array}{c}0.461 * \\
*\end{array}$ & 1 & & & & & & 2.683 \\
\hline $\begin{array}{l}\text { Market Development } \\
\text { Support (Market) }\end{array}$ & $\begin{array}{c}0.462 * \\
*\end{array}$ & $0.711^{* *}$ & 1 & & & & & 2.415 \\
\hline $\begin{array}{l}\text { Supplemental Contact } \\
\text { (Supp) }\end{array}$ & $\begin{array}{c}0.407 * \\
*\end{array}$ & $0.469 * *$ & $0.486^{* * *}$ & 1 & & & & 1.668 \\
\hline $\begin{array}{l}\text { End User } \\
\text { Encouragement } \\
\text { (EndU) }\end{array}$ & $0.193 *$ & $0.387 * *$ & $0.458 * *$ & $0.523 * *$ & 1 & & & 1.553 \\
\hline $\begin{array}{l}\text { Importer Role } \\
\text { Performance (OvPer) }\end{array}$ & $\begin{array}{c}0.584 * \\
* \\
\end{array}$ & $0.590 * *$ & $0.441 * *$ & $0.380 * *$ & $0.240 *$ & 1 & & 1.795 \\
\hline $\begin{array}{l}\text { Exporter Performance } \\
\text { (ExPer) }\end{array}$ & $\begin{array}{c}0.314^{*} \\
*\end{array}$ & $0.291 * *$ & 0.133 & $0.266^{* * *}$ & 0.115 & $\begin{array}{c}0.400 * \\
*\end{array}$ & 1 & \\
\hline
\end{tabular}

NB: $* * \mathrm{p}<0.01$, and $* \mathrm{p}<0.05$

Source: Own study. 


\section{Findings and Discussion}

\subsection{The Influence of Export Incentive on Importer's Role Performance}

Table 3, (Model 1) shows the results of the influence of export incentives of the exporters on the role of importer's performance. The results indicate that export incentives in the dimensions of creditable channel policies and price and financial incentive have positively and significantly affected on importer's role performance (coefficient $=0.414, \mathrm{p}<0.001$, coefficient $=0.508, \mathrm{p}<0.001$ ). Overall, the regression can explain 55.90\% (0.559 of the variation of the dependent variable, importer's role performance. These results are consistent with the study of Obadia and Stottinger (2015) that ascertain export price manipulations in the type of superior margin has positive impact on importer's role performance. Correspondingly, Gilliland and Bello (2002) argue that export incentives support the manufacturer's territory to achieve its economic goals in the distributor's territory. Likewise, the study of Obadia, Bello, and Gilliland (2015) find that export incentives especially the low power incentives (LPIs) (non-monetary incentives) influence the quality of the relationship with foreign distributors. To sum up, Hypothesis 1 is supported.

Table 3. Result of the Regression Analysis

\begin{tabular}{|l|c|c|c|c|}
\hline \multicolumn{1}{|c|}{$\begin{array}{c}\text { Model } \\
\text { Independent Variable (IV) }\end{array}$} & $\begin{array}{c}\mathbf{1} \\
\text { OvPer }\end{array}$ & $\begin{array}{c}\mathbf{2} \\
\text { ExPer }\end{array}$ & $\begin{array}{c}\mathbf{3} \\
\text { ExPer }\end{array}$ & $\begin{array}{c}\mathbf{4} \\
\text { ExPer }\end{array}$ \\
\hline Creditable Channel Policies (Credit) & $0.414^{* * *}$ & $0.315^{* *}$ & & 0.177 \\
Price and Financial Incentive (Price) & $(0.113)$ & $(0.125)$ & & $(0.121)$ \\
& $0.508^{* * *}$ & $0.269^{*}$ & & 0.093 \\
Market Development Support (Market) & $(0.139)$ & $(0.154)$ & & $(0.153)$ \\
& 0.055 & 0.152 & & 0.143 \\
Supplemental Contact (Supp) & $(0.119)$ & $(0.132)$ & & $(0.121)$ \\
& -0.049 & -0.022 & & -0.003 \\
End User Encouragement (EndU) & $(0.103)$ & $(0.114)$ & & $(0.108)$ \\
& 0.004 & 0.124 & & 0.123 \\
Overseas Importer Role Performance & $(0.097)$ & $(0.108)$ & & $(0.102)$ \\
(OvPer) & & & & \\
Operational Capital 1 (DC1) & & & $0.447 * * *$ & $0.366^{* * *}$ \\
& 0.082 & 0.147 & $(0.084)$ & $(0.109)$ \\
Operational Capital 2 (DC2) & $(0.321)$ & $(0.356)$ & $(0.112$ & 0.123 \\
& 0.2 & 0.064 & 0.002 & $(0.232)$ \\
Operational Capital 3 (DC3) & $(0.272)$ & $(0.303)$ & $(0.274)$ & $(0.285)$ \\
& -0.063 & -0.368 & -0.303 & -0.351 \\
Number of Employees 1 (DS1) & $(0.179)$ & $(0.199)$ & $(0.178)$ & $(0.187)$ \\
& 0.173 & 0.444 & 0.349 & 0.382 \\
Number of Employees 2 (DS2) & $(0.165)$ & $(0.183)$ & $(0.17)$ & $(0.174)$ \\
& -0.04 & -0.072 & 0.032 & -0.05 \\
Number of Employees 3 (DS3) & $(0.126)$ & $(0.14)$ & $(0.119)$ & $(0.131)$ \\
& 0.038 & -0.023 & -0.023 & -0.039 \\
Adjusted R & $(0.12)$ & $(0.133)$ & $(0.119)$ & $(0.126)$ \\
\hline
\end{tabular}

NB: ExPer $=$ Exporter Performance, ${ }^{* * *} \mathrm{p}<0.001,{ }^{* *} \mathrm{p}<0.01$, and $* \mathrm{p}<0.05$

Source: Own study. 


\subsection{The Influence of Overseas Importer's Role Performance}

Table 3, (Model 3) shows the findings of the impacts of the overseas importer's role performance on exporter's performance. The results indicate that overseas importer's role performance positively impacts on exporter's performance (coefficient $=0.447, \mathrm{p}<.001)$. The regression can explain $48.1 \%(0.481)$ of the variation of the dependent variable, the exporter's performance. Hence, Hypothesis 2 is supported. The greater the role of the performance of overseas importer, the higher the performance of exporter.

According to the mediating effect of overseas importer role performance toward the association between the exporting incentives (creditable channel policies, price and financial incentives, market development support, supplemental contact, end user encouragement) and exporter's performance, the approach of Baron and Kenny (1986) and Preacher and Hayes (2008) has been adopted to test. First, in accordance with the approach of Baron and Kenny (1986), the impacts of incentives on exporter performance have been investigated. Table 3 (Model 2) informs that export incentives in the dimensions of creditable channel policies and price and financial incentive have positively and significantly affected on exporter's performance (coefficient $=0.315, \mathrm{p}<0.001$, coefficient $=0.269, \mathrm{p}<0.05$ ). Overall, the regression can explain $43.10 \%$ ( 0.431 of the variation of the dependent variable, exporter performance).

Second, the effect of incentives on overseas importer role performance have been detected. As discussed earlier, Model 1 shows that export incentives in the dimensions of creditable channel policies, and price and financial incentives have significant effects on overseas importer's role performance (coefficient $=0.414, \mathrm{p}<$ 0.001 , coefficient $=0.508, \mathrm{p}<0.001$ ). Overall, the regression can explain $55.90 \%$ ( 0.559 of the variation of the dependent variable, overseas importer's performance).

Third, with the approach of Preacher and Hayes (2008), export incentives in the dimensions of creditable channel policies, price and financial incentives, and market development support and overseas importer's role performance have been simultaneously loaded as independent variables to test their effect on exporter's performance. This can be seen in Table 3 (Model 4). It reveals that all export incentives have not significantly affected on exporter's performance (creditable channel policies, coefficient $=0.177, \mathrm{p}>0.05$; price and financial incentives, coefficient $=0.093, \mathrm{p}>0.05$; market development support, coefficient $=.143, \mathrm{p}>$ 0.05 ; supplemental contact, coefficient $=.003, p>0.05$; end user encouragement, coefficient $=0.123, \mathrm{p}>0.05)$. However, the overseas importer role performance shows positive impact on importer role performance $($ coefficient $=.366, \mathrm{p}<0.001)$.

Altogether, the influential degree of export incentives on exporter performance has been changed as non-significance after adding overseas importer's role performance to compute together. The influence of role performance of importer can eliminate 
the influence of export incentives on exporter's performance. This means that the entire effect of export incentives on exporter performance is achieved via importer role performance. In other words, the role performance of importer fully mediates the influence of the export incentives on the performance of an exporter. This leads to the acceptance of Hypothesis 3. This is consistent with previous studies. For instance, Obadia and Stottinger (2015) find that the role performance of an importer fully mediates the relationship between the price manipulations (price and financial incentives) and exporter's economic performance. For this study, the effect of both price and monetary incentives and non-monetary incentives in the form of creditable channel policies on performance of exporter have been mediated by the role performance of the importer. This further provides new insights into the exporting literature. Hence, it is a need to replicate the study in this issue again in the ASEAN country context in the future to compare the results with this study.

\subsection{Managerial and Policy Implications of the Study}

Present and future exporters can benefit from this study. Unique export incentives can be developed over a considerable period, they appear to be the key factors in enabling overseas importers to perform well and avoid behaving opportunistically. Any exporting firms with substantial export incentives providing for overseas importers could outperform to other rivals. Also, making good relationship with overseas importers is one of crucial success factors of exporter since the role of importer is so vital in promoting and supporting sales of exporters internationally. In addition, exporters must learn wisely and appropriately in using both price and monetary and non-monetary incentives to motivate importers. Firm executives and policy makers may also benefit from the findings of the study since an awareness of the determinants of role performance of overseas importer especially export incentives could facilitate firms' strategies.

\section{Limitations of the Study and Future Research Agenda}

According to this study, a considerable limitation is the shortcomings identified in all survey-based research. A weakness of regarding questionnaires as an "objective" approach, followed by rigorous and quantifiable analysis, is that it may seek to elicit opinions which respondents are unwilling to articulate. Following the survey approach prevents the present researcher from undertaking an in-depth investigation of the relationship between export incentives and performance of exporters and overseas importers, which the qualitative method would enable.

In this respect, an interpretivist/qualitative approach might provide a deeper knowledge and understanding of certain aspects of the export incentives in Thailand, since the processes governing the relationship between exporter and importer is influenced not only by purely economic and financial factors, but also by such behavioural factors as trust (Obadia and Vida, 2011), satisfaction with the 
relationship (Shipley and Prinja, 1988), or the risk involved (Cavusgil and Yavas, 1987). Accordingly, present perspective needs to be supplemented in future research with a more behavioural approach.

\section{References:}

Aaby, N., Slater, S. 1989. Management Influences on Export Performance: A Reviews of the Empirical Literature, 1978-1988. International Marketing Review, 6(4), 7-26.

Armstrong, J., Overton, T. 1977. Estimating Nonresponse Bias in Mail Surveys. Journal of Marketing Research, 14, 396-402.

Anderson, J.C., Narus, J.A. 1999. Business Marketing Management: Understanding, Creating, and Delivering Value. Upper Saddle River, NJ: Prentice Hall.

Argouslidis, P.C., Indounas, K. 2010. Exploring the Role of Relationship Pricing in Industrial Export Settings: Empirical Evidence from the UK. Industrial Marketing Management, 39, 460-472.

Aulakh, P.S., Kotabe, M., Teegan, H. 2000. Export Strategy and Performance of Firms from Emerging Economies: Evidence from Brazil, Chile, and Mexico. Academy of Management Journal, 43(3), 342-361.

Aulakh, P.S., Kotabe, M., Sahay, A. 1996. Trust and performance in cross-border marketing partnerships: a behavioral approach. Journal of International Business Studies, 27(5), 1005-1032.

Banerjee, R., Mark, B., Dutta, S., Ray, S. 2012. Applications of Agency Theory in B-to-B Marketing: Review and Future Directions. In G.L. Lilien and R. Grewal (Eds.). Handbook of Business-to-Business Marketing, 41-53. Northampton, MA: Edward Elgar.

Bello, D.C., Gilliland, D.I. 1997. The Effect of Output Controls, Process Controls, and Flexibility on Export Channel Performance. Journal of Marketing, 61, 22-38.

Benabou, R., Tirole, J. 2003. Intrinsic and Extrinsic Motivation. The Review of Economic Studies, 70(3), 489-520.

Bergen, M., Dutta, S., Walker, C.O. 1992. Agency Relationships in Marketing:

A Review. Journal of Marketing, 56(3), 1-24.

Cavusgil, S.T. 1996. Pricing for Global Markets. Columbia Journal of World Business, 31, 66-78.

Chu, W, Desai, P.S. 1995. Channel Coordination Mechanisms for Customer Satisfaction. Marketing Science, 14(4), 343-359.

Ciliberti, F., Pontrandolfo, P., Scozzi, B. 2008. Investigating Corporate Social Responsibility in Supply Chains: A SME perspective. Journal of Cleaner Production, 16(15), 15791588.

Dillman, D.A. 2000. Mail and Internet Surveys: The Tailored Design Method (2nd ed.). New York: Wiley.

Eisenhardt, K.M. 1989. Agency Theory: An Assessment and Review. Academy of Management Review, 14, 57-74.

Fites, D.V. 1996. Make Your Dealers Your Partners. Harvard Business Review, 74, 84-95.

Frazier, G.L. 1999. Organizing and Managing Channels of Distribution. Journal of Academy Marketing Science, 27, 226-240.

Frazier, G.L., Lassar, W.M. 1996. Determinants of Distribution Intensity. Journal of Marketing, 60(4), 39-51.

Gilliland, D.I. 2003. Toward a business-to-business channel incentives classification scheme. 
Industrial Marketing Management, 32, 55-67.

Gilliland, D.I. 2004. Designing channel incentives to overcome reseller rejection. Industrial

Marketing Management, 33(2), 87-95.

Gilliland, D.I., Kim, S. 2014. When do incentives work in marketing channels? Journal of the Academy of Marketing Science, 42(4), 361-379.

Hallén, L., Johanson, J., Seyed-Mohamed, N. 1991. Interfirm Adaptation in Business Relationships. Journal of Marketing, 55, 29-37.

Holmstrom, B., Milgrom, P. 1994. The Firm as An Incentive System. American Economic Review, 84, 972-991.

Hair, J.F., Black, W.C., Babin, B., Anderson, R.E., Tatham, R.L. 2006. Multivariate Data Analysis. New York: Prentice Hall.

Husted, B.W., Allen, D.B. 2007. Corporate social strategy in multinational enterprises: Antecedents and value creation. Journal of Business Ethics, 74(4), 345-361.

Indro, D.C., Richards, M. 2007. The determinants of foreign partner's equity ownership in Southeast Asian joint ventures. International Business Review, 16(2), 177-206.

Jensen, M., Meckling, W. 1976. Theory of the Firm: Managerial Behaviour, Agency Costs, and Ownership Structure. Journal of Financial Economics, 3(2), 305-360.

Krejcie, R.V., Morgan, D.W. 1970. Determining Sample Size for Research Activities. Educational and Psychological Measurement, 30(3), 607-610.

Kumar, S., Bergstrom, T. 2007. An Exploratory Study of the Relationship of Export Intermediaries and Their Trading Partners. Supply Chain Forum, 8(1), 12-31.

Lassar, W.M., Kerr, J.L. 1996. Strategy and Control in Supplier-distributor Relationships: An Agency Perspective. Strategic Management Journal, 17, 613-632.

Mirani, R., Moore, D., Weber, J.A. 2001. Emerging Technologies for Enhancing Supplier-reseller Partnerships. Industrial Marketing Management, 30, 101-114.

Neter, J., Wasserman, W., Kutner, M.H. 1985. Applied Linear Statistical Models: Regression Analysis and Experimental Designs. Irwin, Homewood.

Obadia, C., Bello, D.C., Gilliland, D.I. 2015. Effect of Exporter's Incentives on Foreign Distributor's Role Performance. Journal of International Business Studies, 46(8), 960-983.

Obadia, C., Stottinger, B. 2015. Pricing to Manage Export Channel Relations. International Business Review, 24(2), 311-318.

Obadia, C., Vida, I. 2011. Cross-border relationships and performance: Revisiting a complex linkage. Journal of Business Research, 64(5), 467-475.

Peng, W.M., York, S.A. 2001. Behind Intermediary Performance in Export Trade: Transactions, Agent, and Resources. Journal of International Business Studies, 32(2), 327-346.

Prime, N., Obadia, C., Vida, I. 2009. Psychic distance in exporter-importer relationships: A grounded theory approach. International Business Review, 18(2), 184-198.

Rosenbloom, B. 1990. Motivating Your International Channel Partners. Business Horizons, 33, 53-57.

Nunnally, J.C., Bernstein, I.H. 1994. Psychometric Theory. New York: McGraw-Hill.

Shoham, A. 1998. Export Performance: A Conceptualization and Empirical Assessment. Journal of International Marketing, 6(3), 59-81.

Skarmeas, D., Katsikeas, C.S., Spyropoulou, S., Salehi-Sangari, E. 2008. Market and Supplier Characteristics Driving Distributor Relationship Quality in International Marketing Channels of Industrial Products. Industrial Marketing Management, 37, 23-36.

Suwannarat, P. 2016a. The Study of Export Intermediary Performance Determinants. 
Multinational Business Review, 24(2), 123-143.

Suwannarat, P. 2016b. Export Intermediaries and Their Competency to Reduce Transaction Costs: Examining the Moderating Role of Learning Orientation. Asian Journal of Business and Accounting, 9(2) 181-217.

Suwannarat, P. 2017. Ascertaining the Competitiveness of Thai Exports to PRC,

Competitiveness Review. An International Business Journal, 27(3), 275-299.

Thomsen, S. 1999. Southeast Asia: The role of foreign direct investment policies in Development. Unclassified Working Papers/1999, OECD, Paris.

Williamson, O.E. 1991. Comparative Economic Organization: The Analysis of Discrete Structural Alternatives. Administrative Science Quarterly, 36(2), 269-296.

Zenger, T.R., Marshall, C.R. 2000. Determinants of Incentive Intensity in Group-based Rewards. Academy of Management Journal, 43, 149-163.

Zou, S.C., Taylor, G., Osland, G. 1998. The Expert scale: A Cross-national Generalized Export Performance Measure. Journal of International Marketing, 6(3), 37-58. 